\title{
MODEL PEMBELAJARAN DISCOVERY LEARNING GUNA MEMBENTUK SIKAP PEDULI LINGKUNGAN PADA SISWA SEKOLAH DASAR: SEBUAH KERANGKA KONSEPTUAL
}

\author{
Oleh: \\ ${ }^{1}$ Hayatul Khairul Rahmat, ${ }^{2}$ Syahti Pernanda, ${ }^{3}$ Mutiara Hasanah, \\ ${ }^{4}$ Akhmad Muzaki, ${ }^{5}$ Ela Nurmalasari, ${ }^{6}$ Lathifatuddini Rusdi \\ ${ }^{1}$ Universitas Islam Negeri Sunan Kalijaga, Yogyakarta, Indonesia \\ ${ }^{2}$ Sekolah Dasar Islam Terpadu Buah Hati Padang Utara, Padang, Indonesia \\ ${ }^{3}$ Universitas Negeri Padang, Padang, Indonesia \\ ${ }^{4}$ Universitas Gadjah Mada, Yogyakarta, Indonesia \\ ${ }^{5}$ Universitas Negeri Yogyakarta, Yogyakarta, Indonesia \\ ${ }^{6}$ Sekolah Tinggi Ilmu Tarbiyah Darussalam, Lhokseumawe, Indonesia \\ *email: hayatulkhairul@gmail.com
}

Diterima 2 April 2021, direvisi 30 Juni 2021, diterbitkan 1 Oktober 2021

\begin{abstract}
Abstrak
Penulisan ini bertujuan untuk mendeskripsikan konsep model pembelajaran discovery learning guna membentuk sikap peduli lingkungan pada siswa di sekolah dasar. Adapun penulisan ini menggunakan metode kepustakaan. Model pembelajaran discovery learning merupakan suatu model untuk mengembangkan cara belajar siswa yang aktif dengan menemukan sendiri, menyelidiki sendiri, maka hasil yang diperoleh akan setia dan tahan lama dalam ingatan, tidak akan mudah dilupakan oleh siswa. Melalui model pembelajaran discovery learning membuat siswa mampu menggunakan kemampuan intelektualnya guna memecahkan cara menjaga lingkungan sekitarnya. Sedangkan, sikap peduli lingkungan merupakan suatu sikap dan tindakan yang selalu berupaya mencegah kerusakan pada lingkungan di sekitar dan mengembangkan upaya-upaya untuk memperbaiki kerusakan yang terjadi. Melalui sikap peduli lingkungan siswa sekolah dasar tidak sekedar mengetahui pentingnya menjaga lingkungan tetapi juga menguatkan rasa keingintahuan bagaimana cara menjaga lingkungan. Adapun prosedur implementasi konsep model pembelajaran discovery learning guna membentuk sikap peduli lingkungan pada siswa di sekolah adalah yaitu stimulation (pemberian rangsangan), problem statement (identifikasi masalah), data collection (pengumpulan data), data processing (pengolahan data), verification (pembuktian), dan generalization (menarik kesimpulan).
\end{abstract}

Kata Kunci: Discovery Learning; Model Pembelajaran; Sikap Peduli Lingkungan.

\section{Abstract}

This writing aims to describe the concept of discovery learning learning model in order to form an attitude of caring for the environment in students in elementary schools. This writing uses the library method. Discovery learning learning model is a model for developing active student learning by finding their own, investigating themselves, then the 
ADI WIDYA: Jurnal Pendidikan Dasar FAKULTAS DHARMA ACARYA

UNIVERSITAS HINDU NEGERI

I GUSTI BAGUS SUGRIWA DENPASAR
Volume 6, Nomor 2, Oktober 2021

ISSN: 2685-8312 (online)

ISSN: 2527-5445 (cetak)

http://ejournal.ihdn.ac.id/index.php/AW

results obtained will be loyal and long-lasting in memory, will not be easily forgotten by students. Through the discovery learning model, students are able to use their intellectual abilities to solve ways to protect the surrounding environment. Meanwhile, the attitude of caring for the environment is an attitude and action that always tries to prevent damage to the surrounding environment and develops efforts to repair the damage that occurs. Through an attitude of caring for the environment, elementary school students not only know the importance of protecting the environment but also strengthen their curiosity about how to protect the environment. The procedures for implementing the concept of discovery learning learning models in order to form an attitude of caring for the environment in students in schools are stimulation, problem statements, data collection, data processing, verification, and generalization.

Keywords: Discovery Learning; Learning Model; Environmental Care Attitude.

\section{PENDAHULUAN}

Pada abad 21, literasi sains tidak hanya mengukur tingkat pemahaman terhadap pengetahuan sains, tetapi juga pemahaman terhadap berbagai aspek proses sains, serta kemampuan mengaplikasikan pengetahuan dan proses sains dalam situasi nyata yang dihadapi siswa, baik sebagai individu, anggota masyarakat, serta warga dunia (Kristyowati \& Purwanto, 2019; Rohman, Rusilowati, \& Sulhadi, 2017). Kerangka kerja literasi sains dalam PISA 2015 meliputi empat area, yakni: konteks, kompetensi, sikap, dan pengetahuan. Dari empat area yang disebutkan di atas salah satu yang menjadi fokus yaitu sikap sains khususnya sikap peduli lingkungan. Sikap ini harus dimiliki siswa dalam setiap pembelajaran guna untuk menghadapi berbagai permasalahan di masa yang akan datang.

Peduli lingkungan adalah sikap dan tindakan yang selalu berupaya mencegah kerusakan pada lingkungan alam di sekitarnya dan mengembangkan upaya-upaya untuk memperbaiki kerusakan alam/ kesehatan yang sudah terjadi (Lestari \& Hidayati, 2018). Dengan peduli lingkungan siswa tidak hanya memiliki tentang pemahaman tentang pentingnya kelestarian lingkungan di sekitar melainkan juga pentingnya menjaga kesehatan diri dan orang lain. Praktik penguatan sikap rasa ingin tahu dan peduli lingkungan dapat diwujudkan dengan model pembelajaran yang relevan. Sikap tersebut secara bertahap atau bersamaan terimplementasi dalam perilaku siswa.

Discovery learning didefinisikan sebagai model pembelajaran yang tidak menyampaikan keseluruhan materi (Husna, 2015). Materi disampaikan secara terpisah hanya sebagian saja yang disampaikan secara langsung, sedangkan yang lainnya di temukan sendiri oleh siswa. Siswa didorong untuk aktif dalam menemukan bagian pengetahuan yang belum disampaikan. Secara utuh siswa membangun suatu konsep dan generalisasi dari pecahan temuan-temuan yang mereka dapatkan. Guru membimbing siswa untuk menemukan dan membangun konsep serta generalisasi.

Model discovery learning adalah teori belajar yang didefinisikan sebagai proses pembelajaran yang terjadi bila pelajar tidak disajikan dengan pelajaran dalam bentuk finalnya, tetapi diharapkan mengorganisasi sendiri (Angga Ardianto, Mulyono, \& Handayani, 2019; Desyandri, Muhammadi, Mansurdin, \& Fahmi, 2019). Proses pembelajaran menggunakan model pembelajaran discovery (penemuan) dirancang sedemikian rupa di mana siswa menggunakan kemampuan mental intelektual sendiri 
ADI WIDYA: Jurnal Pendidikan Dasar FAKULTAS DHARMA ACARYA UNIVERSITAS HINDU NEGERI I GUSTI BAGUS SUGRIWA DENPASAR
Volume 6, Nomor 2, Oktober 2021

ISSN: 2685-8312 (online)

ISSN: 2527-5445 (cetak)

http://ejournal.ihdn.ac.id/index.php/AW

dalam memecahkan berbagai persoalan yang dihadapi, sehingga menemukan suatu konsep atau generalisasi yang dapat diterapkan dalam kehidupannya.

Melihat konsep pembelajaran discovery learning yang mengedepan pentingnya pemahaman struktur atau ide-ide penting melalui keterlibatan siswa secara aktif dalam proses proses pembelajaran, maka sangat cocok dan memberikan dampak positif dalam membentuk sikap peduli lingkungan pada siswa di sekolah dasar. Berdasarkan uraian di atas, tulisan ini bertujuan untuk mendeskripsikan konsep model pembelajaran discovery learning guna membentuk sikap peduli lingkungan pada siswa di sekolah dasar.

\section{METODE}

Dalam penyusunan tulisan ini menggunakan metode penelitian kepustakaan (library research) yaitu mengumpulkan semua bahan bacaan yang berkaitan dengan masalah yang dibahas, kemudian memahami secara teliti dan hati-hati sehingga menghasilkan temuan-temuan penelitian (Alawiyah, Rahmat, \& Pernanda, 2020; Ma'rufah, Rahmat, \& Widana, 2020; Rahmat, Banjarnahor, Ma'rufah, \& Widana, 2020). Sebagai pendukung dalam penelitian ini, maka penulis melakukan kegiatan studi literatur yang mendalam yaitu dengan menggunakan penulisan deskriptif.

Metode deskriptif adalah suatu metode dalam meneliti status sekelompok manusia, suatu objek, suatu sistem pemikiran, atau suatu kelas peristiwa pada masa sekarang. Adapun tujuan dari penulisan deskriptif ini adalah untuk membuat deskripsi, gambaran atau lukisan secara sistematis, faktual, dan akurat mengenai fakta-fakta, sifat, serta hubungan antar fenomena yang diselidiki (Widha, Rahmat, \& Basri, 2021). Data yang dikumpulkan dalam penulisan ini adalah data-data sekunder yaitu sumber data penulisan yang diperoleh secara tidak langsung atau melalui media perantara. Data sekunder pada umumnya dapat berupa bukti, catatan, atau laporan historis yang telah disusun dalam arsip (data dokumenter), baik yang dipublikasikan maupun tidak dipublikasikan (Najib \& Rahmat, 2021; Rahmat, Kasmi, \& Kurniadi, 2020)

\section{PEMBAHASAN}

\subsection{Tinjauan Tentang Model Pembelajaran Discovery Learning}

Penemuan (discovery) merupakan suatau metode pembelajaran yang dikembangkan berdasarkan pandangan konstruktivisme (Ilahi, 2002). Pandangan konstruktivisme adalah di mana anak belajar memperoleh pengetahuan yang belum diketahuinya itu tidak melalui pemberitahuan oleh orang guru, baik itu sebagian atau seluruhnya namun anak tersebut menemukan sendiri pengetahuan itu. Metode ini menekankan pentingnya pemahaman struktur atau ide-ide penting terhadap suatu disiplin ilmu, melalui keterlibatan siswa secara aktif dalam proses pembelajaran. Dalam pembelajaran dengan penemuan siswa didorong untuk belajar sebagian besar melalui keterlibatan aktif mereka sendiri dengan konsep-konsep dan prinsip-prinsip dan guru mendorong siswa untuk memiliki pengalaman dan melakukan percobaan yang memungkinkan mereka menemukan prinsip-prinsip untuk diri mereka sendiri. Sedangkan pengertian discovery learning menurut Bruner (dalam Buto, 2010) adalah metode belajar yang mendorong siswa untuk mengajukan pertanyaan dan menarik kesimpulan dari prinsi-prisnsip umum praktis dari contoh pengalaman. Pembelajaran penemuan juga merupakan salah satu Metode pembelajaran dimana siswa didorong untuk belajar sendiri melalui keterlibatan aktif dengan konsep-konsep dan prinsip-prinsip. 
ADI WIDYA: Jurnal Pendidikan Dasar FAKULTAS DHARMA ACARYA UNIVERSITAS HINDU NEGERI I GUSTI BAGUS SUGRIWA DENPASAR
Volume 6, Nomor 2, Oktober 2021

ISSN: 2685-8312 (online)

ISSN: 2527-5445 (cetak)

http://ejournal.ihdn.ac.id/index.php/AW

Pembelajaran discovery learning adalah suatu metode untuk mengembangkan cara belajar siswa aktif dengan menentukan sendiri, menyelidiki sendiri, maka hasil yang diperoleh akan setia, dan tahan lama dalam ingatan dan tidak akan mudah dilupakan oleh siswa. Dengan belajar penemuan, siswa juga bisa belajar berfikir analisis dan mencoba memecahkan sendiri problem yang dihadapi dalam pelajaran, hal ini menjadi suatu kebiasaan yang baik bagi perkembangan siswa. Selain itu, menurut Suprihatiningrum (dalam Ana, 2019), model pembelajaran discovery learning adalah suatu model untuk mengembangkan cara belajar siswa yang aktif dengan menemukan sendiri, menyelidiki sendiri, maka hasil yang diperoleh akan setia dan tahan lama dalam ingatan, tidak akan mudah dilupakan oleh siswa. Dengan belajar penemuan, anak juga bisa belajar berfikir analisis dan mencoba memecahkan sendiri problem yang dihadapi.

Menurut Bell (dalam Hosan, 2014) ada beberapa tujuan spesifik dari pembelajaran dengan penemuan yakni sebagai berikut:

a. Dalam menemukan siswa memiliki kesempatan untuk terlibat aktif dalam pembelajaran.

b. Melalui pembelajaran dengan penemuan, siswa belajar menemukan pola dalam situasi konkret maupun abstrak, juga siswa banyak meramalkan informasi tambahan yang diberikan.

c. Siswa juga belajar merumuskan strategi tanya jawab yang tidak rancu dan menggunakan tanya jawab untuk memperoleh informasi yang bermanfaat dalam menentukan.

d. Pelajaran dengan penemuan membantu siswa membentuk cara kerja bersama yang lebih efektif, saling membagi informasi, serta mendengar, dan menggunakan ide-ide orang lain.

e. Terdapat beberapa fakta yang menunjukkan bahwa keterampilan-keterampilan, konsep-konsep dan prinsip-prinsip yang dipelajari melalui lebih bermakna.

f. Discovery learning keterampilan yang dipelajari dalam situasi belajar penemuan dalam beberapa kasus, lebih mudah ditransfer untuk aktivitas baru dan diaplikasikan dalam situasi belajar yang baru.

Menurut Khairunnisak (2016) berikut beberapa kelebihan belajar mengajar dengan metode discovery learning yaitu sebagai berikut:

a. Dalam penyampaian bahan discovery learning digunakan kegiatan pengalaman langsung.

b. Discovery learning lebih realistis dan mempunyai makna.

c. Discovery learning merupakan suatu Metode pemecahan masalah.

d. Dengan sejumlah transfer langsung, maka kegiatan discovery learning akan lebih mudah diserap oleh anak didik dalam memahami kondisi tertentu yang berkenaan dengan aktivitas pembelajaran.

e. Discovery learning banyak memberikan kesempatan bagi anak didik untuk terlibat langsung dalam kegiatan belajar.

Menurut Suryosubroto (dalam Kristin, 2016) tidak jauh berbeda dengan kelebihan di atas menyebutkan kelebihan metode discovery learning sebagai berikut:

a. Dianggap membantu siswa mengembangkan atau memperbanyak persediaan dan penguasaan keterampilan dalam proses kognitif siswa. 
b. Pengetahuan diperoleh dari Metode ini sangat pribadi sifatnya dan mungkin merupakan suatu pengetahuan yang sagat kukuh; dalam arti pendalaman dari pengertian; retensi dan transfer.

c. Strategi penemuan membangkitkan gairah pada siswa, misalnya siswa merasakan jerih payah penyelidikannya, menemukan keberhasilan kadang-kadang kegagalannya.

d. Metode ini memberikan kesempatan kepada siswa untuk bergerak maju sesuai dengan kemampuannya sendiri.

e. Metode ini menyebabkan siswa mengarahkan sendiri cara belajarnya, sehingga dia lebih merasa terlibat dan termotivasi sendiri untuk belajar.

f. Metode ini dapat membantu memperkuat pribadi siswa dengan bertambahnya kepercayaan pada diri sendiri melalui proses-proses penemuan.

g. Strategi ini berpusat pada anak, misalnya, memberi kesempatan kepada mereka dan guru berpatisipasi dalam mengecek ide.

h. Membantu perkembangan siswa menuju skeptisisme yang sehat untuk menemukan kebenaran akhir yang mutlak.

Menurut Ilahi (2002), adapun kekurangan metode discovery adalah sebagai berikut:

a. Guru merasa gagal mendeteksi masalah dan adanya kesalahpahaman antara guru dengan siswa.

b. Menyita pekerjaan guru.

c. Tidak semua siswa mampu melakukan penemuan.

d. Tidak berlaku untuk semua topik.

e. Berkenaan dengan waktu, strategi discovery learning membutuhkan waktu yang lebih lama daripada ekspositori.

f. Kemampuan berfikir rasional siswa ada yang masih terbatas.

g. Kesukaran dalam menggunakan faktor subjektivitas, terlalu cepat pada suatu kesimpulan.

h. Faktor kebudayaan atau kebiasaan yang masih menggunakan pola pembelajaran lama.

i. Tidak semua siswa dapat mengikuti pelajara dengan cara ini. Di lapangan beberapa siswa masih terbiasa dan mudah mengerti dengan metode ceramah.

j. Tidak semua topik cocok disampaikan dengan metode ini.

\subsection{Tinjauan Tentang Sikap Peduli Lingkungan}

Pada istilah sikap peduli lingkungan terdapat tiga istilah, yaitu sikap, peduli, dan lingkungan. Oleh karena itu, pengertian sikap peduli lingkungan dapat ditinjau dari pengertian dasar sikap, peduli, dan lingkungan. Kata pertama adalah sikap. Dalam Kamus Besar Bahasa Indonesia, sikap berarti perilaku, gerak-gerik, tingkah laku. Sedangkan menurut Ibung (2009), sikap dapat diartikan sebagai pikiran dan perasaan yang mendorong kita bertingkah laku ketika kita menyukai atau tidak menyukai sesuatu. Jadi sikap merupakan respon manusia terhadap stimulus yang diberikan oleh orang lain.

Kata kedua adalah peduli. Dalam Kamus Besar Bahasa Indonesia, peduli berarti mengindahkan, memprihatinkan, menghiraukan, memperhatikan. Menurut Devianti et al. (2020), peduli adalah merasakan kekhawatiran tentang orang lain atau sesuatu. Jadi orang yang peduli adalah orang yang memperhatikan suatu objek. Peduli bukan hanya pada kepada orang lain saja, tetapi bisa juga pada lingkungan sekitarnya. 
ADI WIDYA: Jurnal Pendidikan Dasar FAKULTAS DHARMA ACARYA UNIVERSITAS HINDU NEGERI I GUSTI BAGUS SUGRIWA DENPASAR
Volume 6, Nomor 2, Oktober 2021

ISSN: 2685-8312 (online)

ISSN: 2527-5445 (cetak)

http://ejournal.ihdn.ac.id/index.php/AW

Kata selanjutnya yaitu lingkungan. Menurut Kamus Besar Bahasa Indonesia (dalam Ginanjar, 2013), lingkungan berarti suatu tempat yang mempengaruhi pertumbuhan manusia. Sedangkan menurut Fadlillah \& Khorida (2013), lingkungan adalah suatu suatu tempat atau suasana (keadaan) yang dapat memengaruhi pertumbuhan dan perkembangan seseorang. Begitu pentingnya lingkungan bagi manusia, maka agar lingkungan tetap terjaga dengan baik diperlukan sikap peduli lingkungan.

Jika kata sikap, peduli dan lingkungan disatukan maka dapat diartikan sebagai tingkah laku memperhatikan segala sesuatu yang ada disekitarnya untuk dijaga. Berdasarkan Lestari \& Hidayati (2018), peduli lingkungan adalah sikap dan tindakan yang selalu berupaya mencegah kerusakan pada lingkungan alam di sekitarnya dan mengembangkan upaya-upaya untuk memperbaiki kerusakan alam yang sudah terjadi. Upaya-upaya tersebut seharusnya dimulai dari diri sendiri dan dilakukan dari hal-hal kecil, misalnya membuang sampah pada tempatnnya, menanam tumbuh-tumbuhan, menghemat listrik, dan lain sebagainya. Apabila hal-hal tersebut dilakukan oleh semua orang maka akan tercipta lingkungan yang bersih, indah dan sehat.

Adapun indikator peduli lingkungan untuk siswa kelas 4-6 menurut Kementerian Pendidikan Nasional (dalam Afriyeni, 2018) yaitu membersihkan WC, membersihkan tempat sampah, membersihkan lingkungan sekolah, memperindah kelas dan sekolah dengan tanaman, ikut memelihara taman di halaman sekolah. Adapun contoh indikator keberhasilan untuk kelas menurut Sulistyowati (dalam Hidayati \& Putri, 2019) yaitu membuang sampah pada tempatnya, menjaga kebersihan di kelas, menjaga perilaku hemat energi dan hemat air. Sedangkan menurut Wiyani (dalam Marjohan \& Afniyanti, 2018) indikator peduli lingkungan, yaitu piket kelas secara berkelompok membersihkan kelas, dapat dilakukan setelah pulang sekolah sesuai daftar piket. Siswa secara individu menata bangku dan kursi setiap hari supaya terlihat rapi dan juga setelah pulang sekolah. Tidak mencoret tembok atau bangku/ kursi/ fasilitas sekolah. Bagi yang mencoret diberi sanksi membersihkan atau mengecat ulang.

\subsection{Implementasi Model Discovery Learning dalam Membentuk Sikap Peduli Lingkungan Siswa di Sekolah Dasar}

Menurut Syah (dalam Dewi, Hudiyono, \& Mulawarman, 2018; Suminar \& Meilani, 2016) dalam mengaplikasikan discovery learning di kelas, ada beberapa prosedur yang harus dilaksanakan dalam kegiatan belajar mengajar secara umum sebagai berikut:

a. Stimulation (Stimulasi/ Pemberian Rangsangan). Pada tahap ini siswa dihadapkan pada sesuatu yang menimbulkan tanda tanya, kemudian dilanjutkan untuk tidak memberi generalisasi, agar timbul keinginan untuk menyelidiki sendiri.

b. Problem Statement (Pernyataan/ Identifikasi Masalah). Setelah dilakukan stimulasi, langkah selanjutnya adalah guru memberi kesempatan kepada siswa untuk mengidentifikasi sebanyak mungkin agenda-agenda masalah yang relevan dengan bahan pelajaran, kemudian salah satunya dipilih dan dirumuskan dalam bentuk hipotesis (jawaban sementara atas pertanyaan masalah).

c. Data Collection (Pengumpulan Data). Ketika eksplorasi berlangsung guru juga memberi kesempatan kepada para siswa untuk mengumpulkan informasi sebanyakbanyaknya yang relevan untukmembuktikan benar atau tidaknya hipotesis. Pada tahap ini berfungsi untuk menjawab pertanyaan atau membuktikan benar tidaknya hipotesis. 
ADI WIDYA: Jurnal Pendidikan Dasar FAKULTAS DHARMA ACARYA UNIVERSITAS HINDU NEGERI I GUSTI BAGUS SUGRIWA DENPASAR
Volume 6, Nomor 2, Oktober 2021

ISSN: 2685-8312 (online)

ISSN: 2527-5445 (cetak)

http://ejournal.ihdn.ac.id/index.php/AW

d. Data Processing (Pengolahan Data). Semua informasi hasil bacaan, diolah, diacak, diklasifikasikan, ditabulasi, bahkan bila perlu dihitung dengan cara tertentu serta ditafsirkan pada tingkat kepercayaan tertentu.

e. Verification (Pembuktian). Pada tahap ini siswa melakukan pemeriksaan secara cermat untuk membuktikan benar atau tidaknya hipotesis yang ditetapkan tadi dengan temuan alternatif, dihubungkan dengan data hasil processing.

f. Generalization (Menarik Kesimpulan/ Generalisasi). Tahap generalisasi/ menarik kesimpulan adalah proses menarik sebuah kesimpulan yang dapat dijadikan prinsip umum dan berlaku untuk semua kejadian atau masalah yang sama, dengan memperhatikan verifikasi. Setelah menarik kesimpulan siswa harus memperhatikan proses generalisasi yang menekankan pentingnya penguasaan pelajaran atas makna dan kaidah atau prinsip-prinsip yang luas yang mendasari pengalaman seseorang, serta pentingnya proses pengaturan dan generalisasi dari pengalaman-pengalaman itu.

Melalui prosedur model discovery learning di atas dapat diketahui bahwa dampak dari keteterlaksanaan pembelajaran yang baik dan sangat baik tersebut adalah meningkatnya sikap sikap peduli lingkungan/ kesehatan. Sikap peduli lingkungan/kesehatan yang diukur, mencakup: (1) sikap selalu menjaga kebersihan lingkungan/ kesehatan; (2) peduli lingkungan/ kesehatan terhadap sampah; (3 kepedulian lingkungan/ kesehatan terhadap tanaman yang ada di sekitar; dan (4) kepedulian lingkungan/ kesehatan terhadap kondisi abiotik di sekitar. Hal ini dapat dilihat berdasarkan hasil empiris oleh Winarni (2018) bahwa penggunaan model discovery learning dalam pembelajaran tematik berpengaruh secara signifikan terhadap sikap peduli lingkungan, pemahaman tentnng kompos bagi siswa SD di Kota Bengkulu.

\section{SIMPULAN}

Model pembelajaran discovery learning adalah suatu model untuk mengembangkan cara belajar siswa yang aktif dengan menemukan sendiri, menyelidiki sendiri, maka hasil yang diperoleh akan setia dan tahan lama dalam ingatan, tidak akan mudah dilupakan oleh siswa. Dengan belajar penemuan, anak juga bisa belajar berfikir analisis dan mencoba memecahkan sendiri problem yang dihadapi. Penggunaan model pembelajaran discovery learning dapat meningkatkan sikap peduli lingkungan/ kesehatan, yang mencakup kepedulian terhadap: kebersihan lingkungan/ kesehatan, sampah, tanaman yang ada di sekitar, dan kondisi abiotik di sekitar.

\section{DAFTAR PUSTAKA.}

Afriyeni, Y. (2018). Pembentukan Karakter Anak Untuk Peduli Lingkungan Yang Ada Di Sekolah Adiwiyata Mandiri SDN 6 Pekanbaru Yeni Afriyeni Sekolah Tinggi Persada Bunda Pekanbaru. PAUD Lectura: Jurnal Pendidikan Anak Usia Dini, 1(2), 123-133.

Alawiyah, D., Rahmat, H. K., \& Pernanda, S. (2020). Menemukenali konsep etika dan sikap konselor profesional dalam bimbingan dan konseling. Jurnal MIMBAR: Media Intelektual Muslim Dan Bimbingan Rohani Volume, 6(2), 34-44. https://doi.org/10.47435/mimbar.v6i2.457

Ana, N. Y. (2019). Penggunaan Model Pembelajaran Discovery Learning Dalam Peningkatan Hasil Belajaran Siswa Di Sekolah Dasar. Pedagogi: Jurnal Ilmu Pendidikan, 18(2), 56. https://doi.org/10.24036/fip.100.v18i2.318.000-000 
ADI WIDYA: Jurnal Pendidikan Dasar FAKULTAS DHARMA ACARYA UNIVERSITAS HINDU NEGERI I GUSTI BAGUS SUGRIWA DENPASAR
Volume 6, Nomor 2, Oktober 2021

ISSN: 2685-8312 (online)

ISSN: 2527-5445 (cetak)

http://ejournal.ihdn.ac.id/index.php/AW

Angga Ardianto, Mulyono, D., \& Handayani, S. (2019). Pengaruh Model Discovery Learning Terhadap Hasil Belajar Matematika Siswa Kelas VII SMP. Jurnal Inovasi Matematika, 1(1), 31-37. https://doi.org/10.35438/inomatika.v1i1.136

Buto, Z. A. (2010). Implikasi Teori Pembelajaran Jerome Bruner Dalam Nuansa Pendidikan Modern. Millah, Edisi Khus, 55-69. https://doi.org/10.20885/millah.ed.khus.art3

Desyandri, D., Muhammadi, M., Mansurdin, M., \& Fahmi, R. (2019). Development of integrated thematic teaching material used discovery learning model in grade $\mathrm{V}$ elementary school. Jurnal Konseling Dan Pendidikan, 7(1), 16-22. https://doi.org/10.29210/129400

Devianti, R., Sari, S. L., \& Bangsawan, I. (2020). Pendidikan Karakter Untuk Anak Usia Dini. Mitra Ash-Shibyan: Jurnal Pendidikan Dan Konseling, 03(02), 67-78. https://doi.org/10.46963/mash.v3i02.150

Dewi, P. C., Hudiyono, Y., \& Mulawarman, W. G. (2018). Pengembangan Bahan Ajar Menulis Teks Prosedur Kompleks Dengan Model Pembelajaran Discovery Learning Menggunakan Media Audio Visual (Video) Di Kelas Xi Sma Negeri 1 Samarinda. DIGLOSIA : Jurnal Kajian Bahasa, Sastra, Dan Pengajarannya, 1(2), 101-112. https://doi.org/10.30872/diglosia.v1i2.pp101-112

Fadlillah, M., \& Khorida, L. M. (2013). Pendidikan Karakter Anak Usia Dini. Yogyakarta: Ar-Ruzz Media.

Ginanjar, M. H. (2013). Urgensi Lingkungan Pendidikan Sebagai Mediasi Pembentukan Karakter Peserta Didik. Edukasi Islami Jurnal Pendidikan Islam, 02(Juli), 376-396. Retrieved from https://jurnal.staialhidayahbogor.ac.id/index.php/ei/article/view/37

Hidayati, N., \& Putri, M. B. (2019). Implikasi Kegiatan Partisipatif Program Adiwiyata pada Kampung Binaan (Studi Kasus: SMK N 2 Semarang). Pancasakti Science Education Journal, 4(2), 106-114. https://doi.org/10.24905/psej.v4i2.1387

Hosan, M. (2014). Pendekatan Saintifik dan Kontekstual dalam Pembelajar Abad 21 (G. Indonesia, Ed.). Bandung.

Husna, V. A. (2015). Penggunaan Model Discovery Learning dengan Pendekatan Saintifik Untuk Meningkatkan Hasil Belajar Siswa Kelas V pada Materi Pokok Pesawat Sederhana di MI Walisongo Kebonrowopucang Karangdadap Pekalongan Tahun 2014/2015 (Universitas Islam Negeri Walisongo Semarang). Universitas Islam Negeri Walisongo Semarang. Retrieved from http://eprints.walisongo.ac.id/4602/

Ibung, D. (2009). Mengembangkan Nilai Moral pada Anak. Jakarta: Elex Media Komputindo.

Ilahi, M. T. (2002). Pembelajaran Discovery Strategy dan Mental Vocational Skill. Yogyakarta: Diva Press.

Khairunnisak, K. (2016). Penerapan Metode Discovery Learning Pada Materi Koloid untuk Meningkatkan Hasil Belajar Siswa Kelas XI di SMAN 12 Banda Aceh (Universitas Syiah Kuala). Universitas Syiah Kuala. Retrieved from https://etd.unsyiah.ac.id/index.php?p=show_detail\&id=17819

Kristin, F. (2016). ANALISIS MODEL PEMBELAJARAN DISCOVERY LEARNING DALAM MENINGKATKAN HASIL BELAJAR SISWA SD. Jurnal Pendidikan Dasar PerKhasa, 2(1), 90-98. https://doi.org/10.32734/st.v2i2.532

Kristyowati, R., \& Purwanto, A. (2019). Pembelajaran Literasi Sains Melalui 
ADI WIDYA: Jurnal Pendidikan Dasar FAKULTAS DHARMA ACARYA UNIVERSITAS HINDU NEGERI I GUSTI BAGUS SUGRIWA DENPASAR
Volume 6, Nomor 2, Oktober 2021

ISSN: 2685-8312 (online)

ISSN: 2527-5445 (cetak)

http://ejournal.ihdn.ac.id/index.php/AW

Pemanfaatan Lingkungan. Scholaria: Jurnal Pendidikan Dan Kebudayaan, 9(2), 183-191. https://doi.org/10.24246/j.js.2019.v9.i2.p183-191

Lestari, Y., \& Hidayati, H. (2018). Penanaman Nilai Peduli Lingkungan Dalam Pembelajaran Ilmu Pengetahuan Alam. Trihayu: Jurnal Pendidikan Ke SD-An, 4(2), 332-337. https://doi.org/10.30738/trihayu.v4i2.2238

Ma'rufah, N., Rahmat, H. K., \& Widana, I. D. K. K. (2020). Degradasi moral sebagai dampak kejahatan sibel pada generasi millenial di Indonesia. NUSANTARA: Jurnal Ilmu Pengetahuan Sosial, 7(1), 191-201.

Marjohan, M., \& Afniyanti, R. (2018). Penerapan Nilai Pendidikan Karakter Peduli Lingkungan Di Kelas Tinggi Sekolah Dasar. Jurnal Gentala Pendidikan Dasar, 3(1), 111-126. https://doi.org/10.22437/gentala.v3i1.6767

Najib, A., \& Rahmat, H. K. (2021). Analisis Pelaksanaan Program Desa Tangguh Bencana di Desa Buluh Cina, Siak Hulu, Kampar, Riau. Jurnal Ilmiah Muqoddimah: Jurnal Ilmu Sosial, Politik Dan Humaniora, 5(1), 14-23.

Rahmat, H. K., Banjarnahor, J., Ma'rufah, N., \& Widana, I. D. K. K. (2020). Pemberdayaan Masyarakat Oleh Bintara Pembina Desa (Babinsa) Dalam Meningkatkan Kesejahteraan Rakyat. Jurnal Ilmu Pengetahuan Sosial, 7(1), 91107.

Rahmat, H. K., Kasmi, K., \& Kurniadi, A. (2020). Integrasi dan Interkoneksi antara Pendidikan Kebencanaan dan Nilai-Nilai Qur'ani dalam Upaya Pengurangan Risiko Bencana di Sekolah Menengah Pertama. Prosiding Konferensi Integrasi Interkoneksi Islam Dan Sains, 2(1), 455-461. Retrieved from http://sunankalijaga.org/prosiding/index.php/kiiis/article/view/440

Rohman, S., Rusilowati, A., \& Sulhadi, S. (2017). Analisis Pembelajaran Fisika Kelas X SMA Negeri di Kota Cirebon Berdasarkan Literasi Sains. Physics Communication, 1(2), 12-18. https://doi.org/10.15294/physcomm.v1i2.10402

Suminar, S. O., \& Meilani, R. I. (2016). Pengaruh Model Pembelajaran Discovery Learning Dan Problem Based Learning Terhadap Prestasi Belajar Peserta Didik. Jurnal Pendidikan Manajemen Perkantoran, 1(1), 80-89. https://doi.org/10.17509/jpm.v1i1.3339

Widha, L., Rahmat, H. K., \& Basri, A. S. H. (2021). A Review of Mindfulness Therapy to Improve Psychological Well-being During the Covid-19 Pandemic. Proceeding of International Conference on Science and Engineering, 4(February), 383-386.

Winarni, E. W. (2018). Pendekatan Ilmiah dalam Pembelajaran Kreatif dan Inovatif. Bengkulu: FKIP UNIB Press. 